\title{
P313: Prehospital care: analysis of serological status and vaccination coverage for Hepatitis B on injured workers
}

\author{
MHRS Paiva*, ACD Oliveira, AOD Paula \\ From 2nd International Conference on Prevention and Infection Control (ICPIC 2013) \\ Geneva, Switzerland. 25-28 June 2013
}

\section{Introduction}

Immunization of health professionals is critical to the prevention of various diseases and is one of the factors associated with reduced mortality from these diseases.

\section{Objectives}

The aim was to determine the prevalence of accidents involving exposure to biological material and the vaccinal and serological situation for Hepatitis B and the immunization against tetanus and diphtheria of injured professionals of the mobile emergency medical services of the State of Minas Gerais.

\section{Methods}

An epidemiological study with a cross-sectional design was carried out, involving professionals from the Emergency Medical Services in the State of Minas Gerais. Data were collected between December 2011 and July 2012, using a structured questionnaire, and then typed and analyzed in SPSS statistical software, version 18.0. Characterization of population, vaccination coverage for tetanus, diphtheria, Hepatitis B and serological status for Hepatitis $B$ was verified through calculation of absolute and relative frequencies.

\section{Results}

The prevalence of accidents involving biological material was $17.0 \%$ (83/487). Vaccinal coverage for Hepatitis B, among injured professionals was $96.5 \%$, of whom $66.1 \%$ confirmed that they had had three doses of this immunization, $41.9 \%$ confirmed that they had done the anti-HB test, with $25.7 \%$ stating that they were reactive, $9.8 \%$ nonreactive, and $64.5 \%$ stating that they did not know. The

Universidade Federal de Minas Gerais, Belo Horizonte / Minas Gerais, Brazil vaccinal coverage for tetanus and diphtheria reached $96.3 \%$ with $75.8 \%$ informing that the last reinforcing dose had been administered less than ten years previously.

\section{Conclusion}

Based on these results, it is suggested that workplaces evaluated promote an adequate vaccination coverage and monitoring of vaccination and serological status of these workers.

\section{Disclosure of interest}

None declared.

Published: 20 June 2013

doi:10.1186/2047-2994-2-S1-P313

Cite this article as: Paiva et al:: P313: Prehospital care: analysis of serological status and vaccination coverage for Hepatitis $B$ on injured workers. Antimicrobial Resistance and Infection Control 2013 2(Suppl 1):P313.

Submit your next manuscript to BioMed Central and take full advantage of:

- Convenient online submission

- Thorough peer review

- No space constraints or color figure charges

- Immediate publication on acceptance

- Inclusion in PubMed, CAS, Scopus and Google Scholar

- Research which is freely available for redistribution

Submit your manuscript at www.biomedcentral.com/submit 